\title{
El vuelo de la alondra de Mario Bencastro
}

DOI: http://dx.doi.org/10.5377/koot.v0i10.6706 URI: http://hdl.handle.net/11298/792

\author{
Mario Bencastro \\ Escritor y novelista \\ www.MarioBencastro.org \\ mbencastro@bellsouth.net
}

\section{Presentación}

En esta intrigante novela el autor combina su experiencia de pintor con su inventiva literaria para ofrecernos una "ficción pictórica", en que la realidad y el arte convergen formando un mundo alucinante.

Un experto en arte, Marc Douanier, es enviado a San Salvador por una subastadora de París para adquirir la obra de un artista local, que la crítica internacional califica como "magistral expresión del realismo fantástico del nuevo mundo" y está siendo solicitada por importantes galerías, museos y colecciones privadas que incrementan rápidamente su valor monetario.

Para llevar a cabo su misión el experto debe sortear situaciones extrañas como pinturas robadas y falsificadas, y sectas secretas que dificultan su tarea, encima de que el país del artista se encuentra en una convulsión política y social que le recuerda la histórica revolución francesa que conmocionó a su propia tierra hace siglos.

Marc Douanier trae el especial encargo de comprar una pintura del artista salvadoreño para la colección del Museo de Louvre, pero antes debe resolver un misterio: ¿Por qué los cuadros quedan en blanco? ¿Qué sucede con los personajes de las pinturas? ¿Se escapan ellos de su prisión de colores siguiendo al pueblo que lucha por liberarse de un opresivo sistema?

El lema de Benjamín Cañas "Pinto la realidad como yo la imagino" colorea estas páginas, y sus personajes pictóricos cobran vida en este mural novelesco. "Benjamín Cañas fue un virtuoso, un pintor inédito, reflexivo, que dejó una herencia al arte latinoamericano y al mundo." -Bélgica Rodríguez, Directora del Museo de Arte de las Américas, Washington DC, EEUU, (1988-1994).

Palabras claves: Literatura; Arte; Pintura 


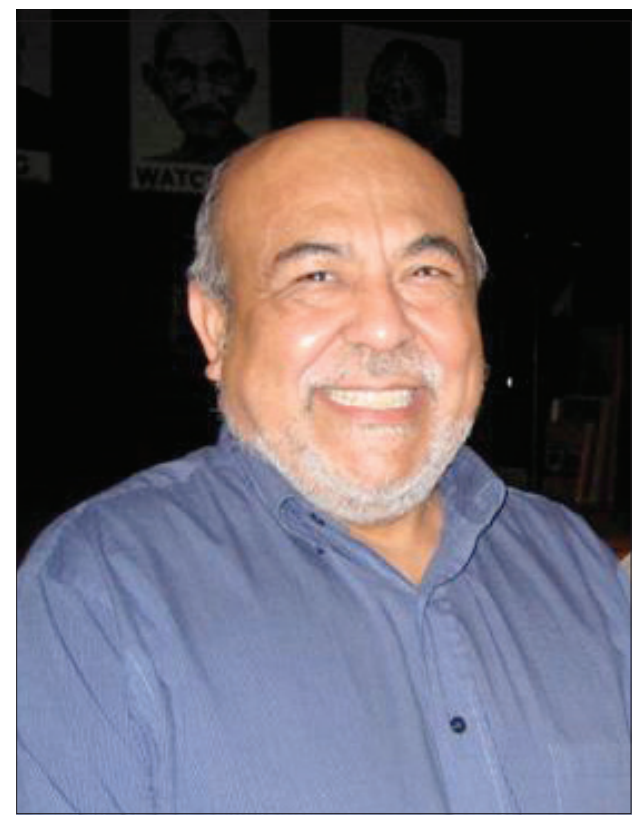

Mario Bencastro

\begin{abstract}
In addition to his literary inventiveness, the author's experience as a painter is also combined in this intriguing novel in order to offer the readership a "pictorial fiction" where art and reality converge to shape a hallucinating world.

Marc Douanier, an art expert, is sent to San Salvador by a Parisian auctioneer with the purpose of purchasing the work of a local artist that has been internationally qualified as a "master expression of the fantastic realism of the new world" and it's being sought after by well-known art galleries, museums and private collections that rapidly increase its money value.
\end{abstract}

To accomplish his mission, the art expert has to avoid odd situations like falsified and stolen pieces of art, and the work of secret sects that make his task even more difficult. On top of that, the homecountry of the artist is undergoing a political and social convulsion that reminds him of the historic French Revolution, which happened to affect deeply his own land centuries ago.

Marc Douanier has a special assignment: buying a painting by the Salvadorean artist to be included in the collection of the Louvre Museum, nonetheless, he first has to solve a mystery: why are the paintings blank? where have the characters 
gone? are they running away from their canvas prison to follow the people who struggle to break free from an oppressive system?

Benjamín Cañas'motto "I paint reality the way I imagine it" is painting these pages and his pictorial characters turn to life in the walls of this novel.

"Benjamín Cañas was a virtuoso, an unprecedented reflexive painter who left a legacy to the Latin American art and the world."--Bélgica Rodríguez, Director for the Museo de Arte de las Américas, Washington, D.C., EUA, (1988-1994).

Keywords: Literature; Art; Painting

\section{Acerca del autor}

Mario Bencastro (El Salvador, 1949), es escritor y pintor acreedor de premios nacionales e internacionales, cuyas obras literarias se han traducido al inglés, francés y alemán, publicadas en El Salvador, México, Canadá, Estados Unidos y Alemania.

Inició su trayectoria artística en la pintura, granjeándose éxitos a temprana edad, exponiendo su obra en más de cuarenta y siete exposiciones en galerías y museos de El Salvador, Estados Unidos, América Latina y Europa.

El drama político y social de su país lo influenció a incursionar en la literatura. $\mathrm{Su}$ primera novela Disparo en la catedral — histórica e innovadora que inicia con el golpe de estado en El Salvador en 1979 y recoge el homicidio de Monseñor Romero- fue Finalista en el Premio Literario Internacional Novedades y Diana, México, 1989.

Su obra también explora la vida del inmigrante centroamericano en Estados Unidos y Australia. Odisea del Norte, Premio de Editores Independientes, (Finalista), ha sido descrita como "Una historia épica de opresión política y exilio, creíble y sumamente impresionante.” (Kirkus, EEUU).

Otras obras: Paraíso portátil, (2010), colección de cuento, poesía y novela breve. La mansión del olvido, (2015), obtuvo el Premio Internacional del Libro Latino 2016, EEUU, "Mejor novela de ficción histórica," y ha sido recomendada por la revista Library Journal como "Libro esencial para todas las bibliotecas." Olas del East River, (2017), "es un texto extraordinario por la riqueza de sus registros y las voces whitmanianas que logra convocar." (Rei Berroa, George Mason University, EEUU.) 


\section{Referentes bibliográficos}

Bencastro, Mario. (2018). El vuelo de la alondra. Estados Unidos. Ediciones Puerto Santa Lucía.

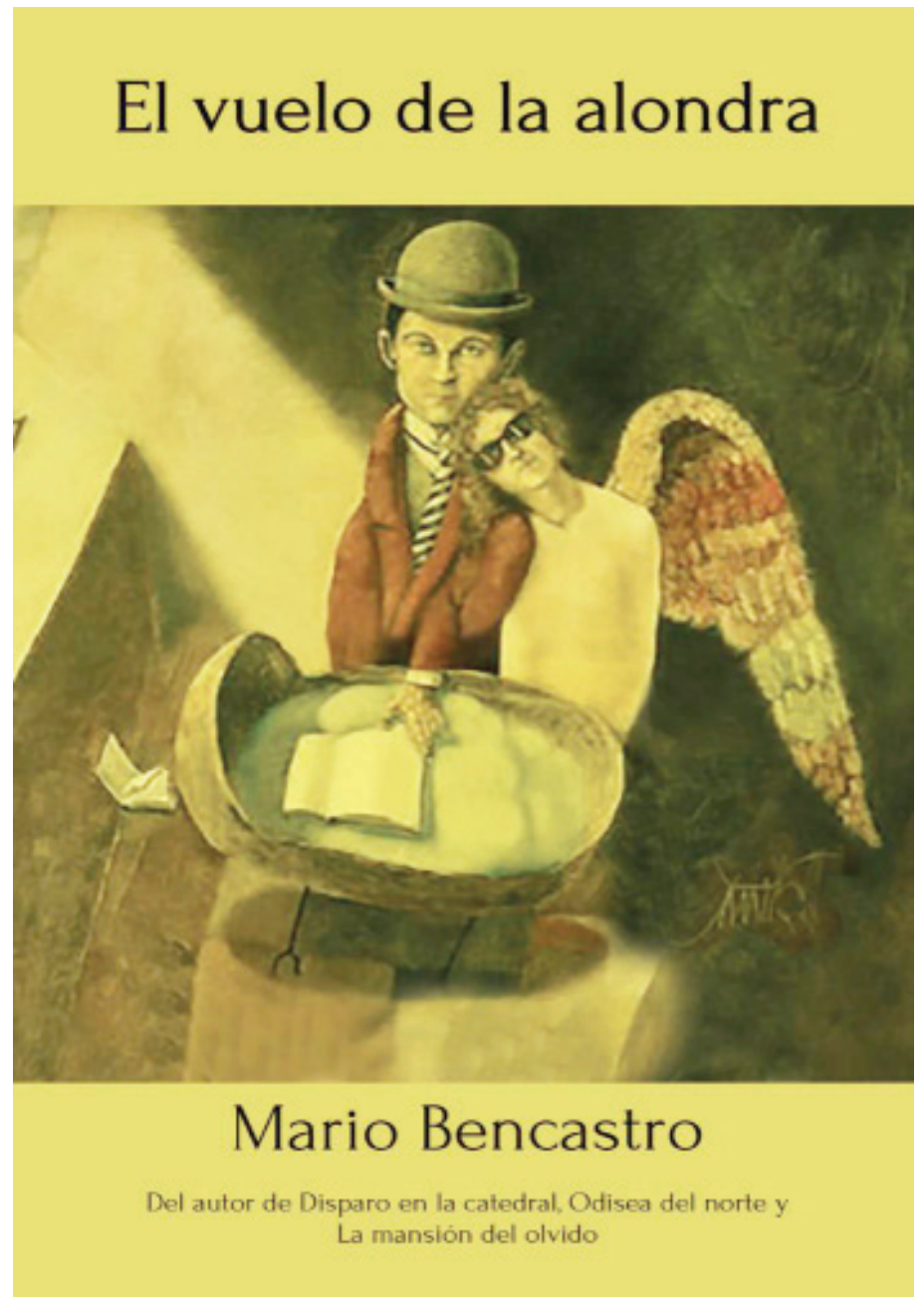




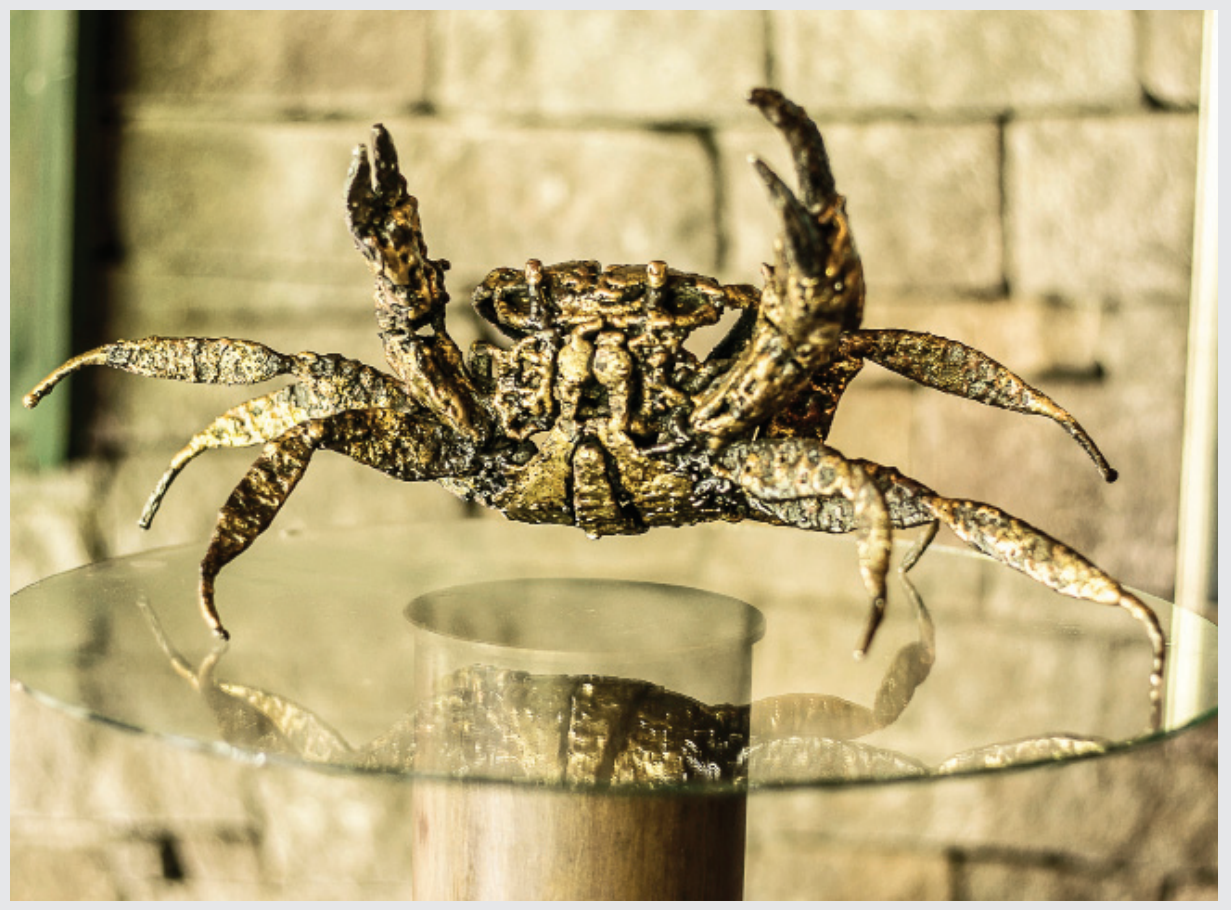

Rubén Martínez Bulnes 